(c) American Dairy Science Association, 2005.

\title{
Storage Stability of Lutein During Ripening of Cheddar Cheese
}

\author{
S. T. Jones, ${ }^{1}$ K. J. Aryana, ${ }^{1,2}$ and J. N. Losso ${ }^{1}$ \\ ${ }^{1}$ Department of Food Science, and \\ ${ }^{2}$ Department of Dairy Science, Louisiana State University Agricultural Center \\ Baton Rouge 70803
}

\begin{abstract}
Lutein (3,3'-dihydroxy- $\alpha$-carotene) has been identified as a dietary factor that can delay the onset of agerelated macular degeneration (AMD). However, available food sources of lutein contain only modest amounts of the carotenoid. Food fortification with lutein extract has been identified as a low-budget approach to prevent the onset or progression of AMD. The objectives of this study were to 1 ) incorporate various amounts of lutein into Cheddar cheese; 2) examine the color, $\mathrm{pH}$, microbiological, and sensory characteristics of the Cheddar cheese during storage; and 3) analyze the stability of lutein during the cheese maturation process. Lutein extracted from corn was added to Cheddar cheese in quantities of 1,3 , and $6 \mathrm{mg}$ per serving size. Measurements of the lutein stability were carried out by HPLC using a $\mathrm{YMC} \mathrm{C}_{30}$ carotenoid column. Microbiological analyses of cheese samples included aerobic plate count, coliform, and yeast/mold counts. The color attributes $\mathrm{a}^{*}$ and $\mathrm{b}^{*}$ were significantly different between the treatment and control groups; however, no significant difference was observed in $\mathrm{L}^{*}$ value and $\mathrm{pH}$. Significant differences among 1,3 , and $6 \mathrm{mg}$ lutein-enriched cheeses were observed in the aerobic plate count and yeast/mold compared with the control. Cheese samples contained no detectable levels of coliforms ( $<10 \mathrm{cfu} / \mathrm{g})$. The HPLC data showed quantitative recovery of lutein during the storage period, and no lutein degradation products were identified. These results indicate that lutein, a functional additive with purported ability to prevent or reduce the onset of AMD, can be incorporated into cheese adding value to this product.
\end{abstract}

(Key words: lutein, fermented, dairy, age-related macular degeneration)

Abbreviation key: AMD = age-related macular degeneration, $\mathbf{A P C}=$ aerobic plate count, $\mathbf{Y} / \mathbf{M}=$ yeasts $/$ molds.

Received August 30, 2004.

Accepted January 24, 2005.

Corresponding author: J. N. Losso; e-mail: jlosso@agctr.lsu.edu.

\section{INTRODUCTION}

Age-related macular degeneration (AMD) is the most common cause of severe vision loss in the developed world, especially affecting elderly people (Stone et al., 2001; La Cour et al., 2002). The disease is characterized by the appearance of drusen in the macula, accompanied by choroidal neovascularization (La Cour et al., 2002). The etiology of age-related macular degeneration is complex; however, risk factors include genetic, age, smoking, race, gender, iris color, diabetes and its complications (retinopathy and nephropathy), atherosclerosis, low antioxidant intake, inflammation, educational status, sunlight exposure, and nutrition (AREDS, 2001; Stone et al., 2001; Krinsky et al., 2003; Zhao et al., 2003; Miranda et al., 2004). Moreover, the number of people affected by this disease is expected to nearly double in the next $25 \mathrm{yr}$.

Treatment options available for AMD involve slowing down the angiogenic process of AMD by laser or photodynamic therapies. Laser treatment carries the possibility of damaging the remaining vision. Photodynamic therapy is a Food and Drug Administration-approved and commonly performed therapy, but certainly not a definitive treatment (Bernstein, 2002; Zhao et al., 2003). As standard therapies for macular degeneration are limited, costly, and often associated with undesirable pathological side effects, the role of nutrition in protecting against AMD is under intensive consideration (Basu et al., 2001; Bernstein, 2002; Zhao et al., 2003).

Lutein (3,3'-dihydroxy- $\alpha$-carotene) has been identified as a dietary carotenoid that can delay the onset of AMD (Seddon et al., 1994). A wealth of evidence suggests that macular levels that are high in lutein may protect against AMD, whereas low levels of lutein are often measured in the diet, serum, and eyes of individuals with clinical histories of AMD (EDCC, 1993; Seddon et al., 1994; Mares-Perlman et al., 2001; Bernstein, 2002). However, definitive prospective clinical studies remain to be conducted (Bernstein, 2002).

One of the most important biochemical mechanisms underlying the preventive activity of a carotenoid such as lutein is the stimulation of intercellular gap junction communication. Lutein is an efficient inducer of inter- 
cellular gap junction communication, whereas $\alpha$-carotene and lycopene are less active (Basu et al., 2001). Another hypothesized protective effect of lutein accumulation is the ability to absorb light in the blue wavelengths that impinges directly on the fovea of the retina, and the special ability of carotenoids to quench singlet oxygen and other reactive oxygen species, therefore protecting the macular cells during a lifetime of oxidative stress (Bowen et al., 2002).

Seddon et al. (1994) suggested that $6 \mathrm{mg}$ of lutein a day might reduce the risk of AMD by up to $43 \%$. This concentration is equivalent to consuming $2 \mathrm{lbs}$ of corn, 2 salad bowls of spinach, or one salad bowl of kale a day. Very few people have the discipline to consistently consume $2 \mathrm{lbs}$ of corn daily for lutein intake. As a result, food fortification with lutein extract is convenient and appealing to health conscious consumers.

Cheese is a favorite North American food. It is a critical component of meals and snacks offered in the school breakfast/lunch programs throughout the United States (USDA Food and Nutrition Service, 2004; WIC Food Package, 2004). Cheese is also consumed worldwide in different forms. Cheddar cheese is a major contributor of essential nutrients (calcium, protein, phosphorus, potassium, riboflavin, vitamin A, vitamin $\mathrm{B}_{12}$, and niacin), all of which improve the overall nutritional quality of growing adolescents' and adults' diets (Cook and Friday, 2003; Stang and Bayerl, 2003). We hypothesized that Cheddar cheese fortified with lutein would allow ingestion of the suggested minimum daily intake of the carotenoid and could be identified as a low budget treatment for prevention of the onset and progression of AMD. The objectives of this study were 1) to incorporate various amounts of lutein into Cheddar cheese; 2) to examine the color, $\mathrm{pH}$, microbiological, and sensory characteristics of the Cheddar cheese during storage; and 3) analyze the stability of lutein during the cheese maturation process.

\section{MATERIALS AND METHODS}

\section{Cheese Manufacture}

Milk processing and cheese making. Raw milk was obtained from the Department of Dairy Science Creamery Plant at Louisiana State University (Baton Rouge, LA). Milk was standardized to 3.5\% milk fat to make full-fat cheese (Haque et al., 1997). Cheddar cheese was made according to Kosikowski (1982) with minor modifications. Lutein was added just before hooping to retain the carotenoid. Cheddar cheese was made in duplicate per concentration of lutein $(1,3$, and $6 \mathrm{mg}$ per serving size (28g) of the finished product); no lutein was added to the control Cheddar cheese. Cheese was vacuum packed using the Multivac A 300/52 (Sepp Hag- genmüller KG, Kansas City, MO) in Cryovac high-density polythene bags (Cryovac Seal Air Corporation, Duncan, SC) and aged for $24 \mathrm{wk}$ in a walk-in cooler (Vollrath Refrigeration Division, River Falls, WI) at $4.5^{\circ} \mathrm{C}$.

\section{Lutein Extraction Process}

Corn samples $(100 \mathrm{~g})$ were extracted 3 times with $300 \mathrm{~mL}$ of acetone each. The acetone extracts were combined and acetone was evaporated under vacuum using a rotary evaporator. The extract was saponified with $200 \mathrm{~mL}$ of $10 \% \mathrm{KOH}$ in methanol for $12 \mathrm{~h}$ with gentle shaking in the dark. Five hundred milliliters of a mixture of ether:hexane (1:1) and $100 \mathrm{~mL}$ of water were added to the methanolic solution and the mixture was shaken gently for $10 \mathrm{~min}$. Lutein (in the upper ether:hexane phase) was removed using a separatory funnel. The extraction was repeated 3 times, and the ether:hexane extracts were combined and evaporated under vacuum. The recovered lutein was dissolved in ethanol, the solvent was removed under vacuum, and this step (ethanol dissolution and ethanol removal) was repeated 3 times to remove all traces of ether:hexane mixture. The recovered lutein was stored at $-20^{\circ} \mathrm{C}$ until use.

\section{Color Measurement}

Color analyses were performed using a handheld colorimeter (Minolta CM 508d; Minolta Laboratories, Osaka, Japan). The $\mathrm{L}^{*}, \mathrm{a}^{*}$, and $\mathrm{b}^{*}$ color measurements were determined according to the CIELAB color space. The $\mathrm{L}^{*}$ value corresponds to lightness (changing from $0 \%$ dark to $100 \%$ light), a* value corresponds to red/ green (changing from $-60 \%$ green to $+60 \%$ red), and $b^{*}$ value corresponds to yellow/blue chromaticity (changing from $-60 \%$ blue to $+60 \%$ yellow) (Banavara et al., 2003; Pinho et al., 2004). The colorimeter was calibrated with a $100 \% \mathrm{~L}^{*}$ standard ceramic cap before each use. On average, 5 readings per sample were recorded.

\section{pH Measurements}

The $\mathrm{pH}$ was measured using an ATI Orion model 350 $\mathrm{pH}$ meter (Boston, MA) which was calibrated before use with reference solutions $\mathrm{pH} 4.0$ and $\mathrm{pH} 7.0$ buffers (Fisher Scientific, Fairlawn, NJ). Cheese pH was measured at $22^{\circ} \mathrm{C}$ by inserting the electrode directly into the cheese samples.

\section{Microbiological Analyses}

Cheese sampling and sample preparation. Microbiological analyses were performed on all cheeses. 
Cheeses were sampled at wk 1,12 , and 24 of storage. A cross-sectional slice, $1 \mathrm{~cm}$ thick, was removed from the center of the 19-kg block of cheese. Using a sterile mortar and pestle, $1 \mathrm{~g}$ of sample was homogenized with $99 \mathrm{~mL}$ of $0.1 \%$ peptone water solution (Becton Dickinson Co., Sparks, MD). Then, according to each sample, 10 -fold serial dilutions from $10^{-2}$ to $10^{-7}$ were prepared using the same diluent and subsequently plated onto aerobic plate count (APC), coliform, and yeast/mold (Y/M) petrifilms (3M Petrifilm, St. Paul, MN). Coliform counts were determined after incubation at $32^{\circ} \mathrm{C}$ for 24 $\mathrm{h}$. The APC counts were obtained after incubation at $32^{\circ} \mathrm{C}$ for $48 \mathrm{~h}$. Yeast/mold counts were recorded after incubation at $25^{\circ} \mathrm{C}$ for $5 \mathrm{~d}$.

\section{Sensory Analyses}

After 24 wk of aging, the middle portions of the aged cheeses (in triplicate) were cut into $2.5 \times 2.5 \times 3.75 \mathrm{~cm}$ pieces. The freshly cut cheese samples were placed into random coded (3-digit) clear containers (Solo, Urbana, IL) and immediately covered with lids to avoid drying. The cheese samples were presented to panelists in completely randomized order. The 5 trained panelists tasted 4 cheeses and rated the sensory attributes using the ADSA score card for Cheddar cheese (Mississippi State Univ. Ext. Serv., 2004). Flavor was scored using a 1-to-10 hedonic scale $(1=$ dislike extremely to $10=$ like extremely). The body/texture and color/appearance were judged on a 1-to-5 hedonic scale ( 1 = dislike extremely to $5=$ like extremely). The sensory analysis was approved by the Institutional Research Board HE 04-16 (Louisiana State University). Criticisms describing any off-flavors, body/texture, or color/appearance were recorded during the evaluation of the cheese.

\section{Lutein Analysis by HPLC}

Cheese portions ( $28 \mathrm{~g}$ ) were cut into small pieces and pressed in the mortar and pestle for $30 \mathrm{~s}$. The samples were shaken for $1 \mathrm{~h}$ and extracted twice with $100 \%$ acetone. The supernatants were collected, filtered, and evaporated to dryness under dim light to minimize photodegradation, isomerization, and structural changes of the pigments (Bonora et al., 2000).

The extracted lutein was saponified with $10 \% \mathrm{KOH}$ in methanol with gentle shaking in the absence of light at $22^{\circ} \mathrm{C}$. The saponified sample was poured into a 250 $\mathrm{mL}$ separatory funnel. The carotenoid was extracted with a 1:1 mixture of ether/hexane. The bottom aqueous layer was drained into a $250-\mathrm{mL}$ waste container, and the diethyl ether/hexane layer in the separatory funnel was poured into a glass container. The extraction was repeated until the extract was colorless. The extracts were combined, and the solvents were evaporated to dryness under vacuum. The carotenoid extracts was added to $20 \mathrm{~mL}$ methyl tertiary-butyl ether (MTBE) and separated by HPLC analysis.

Three milliliters of lutein extracts and the standards were filtered through a $0.45-\mu \mathrm{m}$ polytetrafluoroethylene filter membrane (Sigma Aldrich, St. Louis, MO). The filtered samples were injected into a $\mathrm{YMC} \mathrm{C}_{30}$ carotenoid $3-\mu \mathrm{m}, 4.6 \times 250 \mathrm{~mm}$ HPLC column (waters, Milford, MA). The HPLC separation was carried using Water model $600 \mathrm{E}$ solvent delivery system fitted with a model 717A plus autosampler, with a model 486 tunable absorbance detector and Millennium 32 chromatography manager with processor (Milford, MA). The flow rate was $1 \mathrm{~mL} / \mathrm{min}$, detection was at $450 \mathrm{~nm}$, and separation was isocratic using methyl tertiary-butyl ether:methanol (5:95) as the mobile phase, with a total separation time of $30 \mathrm{~min}$.

A standard curve was constructed using pure standard lutein. Peak areas of lutein (1,3, and $6 \mathrm{mg}$ per serving size) in cheese samples were fitted to the standard curve and corresponding values in milligrams per liter were recorded.

\section{Statistical Analyses}

All tests were performed in triplicates for reproducibility. Significant differences were determined at $P<$ 0.05. Data from color, $\mathrm{pH}$, microbiological (the number of colony forming units were transformed to $\log 10$ ), and sensory evaluation were analyzed by SAS version 8.02 using the GLM procedure (SAS Institute, Inc., Cary, NC). Values are presented as means \pm standard error of the means (SEM). To represent the statistical values in the graphics, SEM bars were used.

\section{RESULTS AND DISCUSSION}

\section{Color Measurement}

Color is an important criterion used to evaluate cheese quality, and this parameter is often a primary consideration for consumers when making purchasing decisions. Color perception differs from person to person and depends on the lighting and other factors; some industries rely on human vision coupled with an instrumental system of color measurement. These instruments attempt to simulate the manner in which the average eye sees the color of cheese under specified conditions (Pinho et al., 2004). The objective was to measure the color differences of control and lutein-enriched cheeses during maturation. The mean $L^{*}$ values are reported in Figure 1. The $L^{*}$ value increased significantly from wk 1 to 24 during storage in the control and lutein-enriched cheeses. In the first week, the $\mathrm{L}^{*}$ 


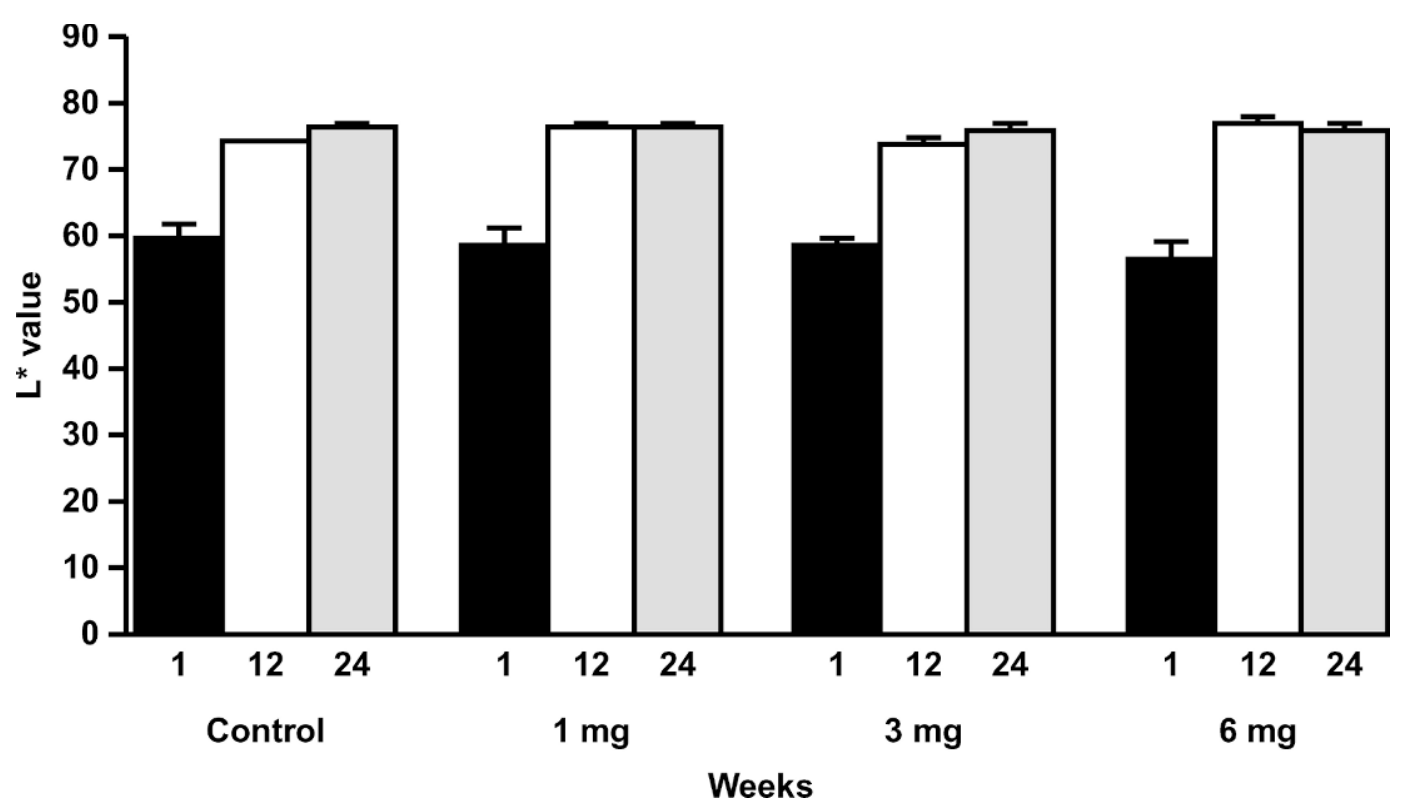

Figure 1. Lightness $\left(\mathrm{L}^{*}\right)$ values (mean $\pm \mathrm{SE}$ ) of Cheddar cheese containing $0,1,3$, and $6 \mathrm{mg}$ of lutein per 28-g serving for 1 , 12 , and 24 wk of storage at $4.5^{\circ} \mathrm{C}$.

value ranged from 57.29 to 58.62 . However, by wk 24 , the $\mathrm{L}^{*}$ values increased to 75.61 and 76.69 in the control and lutein-enriched cheeses, respectively. The control cheese and cheese enriched with $3 \mathrm{mg}$ of lutein had the lowest $L^{*}$ values throughout the 24 -wk aging period. In addition, there were no significant differences between the control and lutein-enriched cheese samples. Lightness was not considered significant due to the prominent pigmentation contributed by lutein. Therefore, it is probable that lutein had no role in the increase of $\mathrm{L}^{*}$ value. The increase in lightness may be due to the breakdown of pigments during ripening (Saldo et al., 2002).

The $\mathrm{a}^{*}$ values were considered important variables due to the pigmentation characteristics of lutein that augments the appearance of the cheese, which is noted in the sensory evaluation. The mean $a^{*}$ values are shown in Figure 2. The results revealed that the red component was significant in the 1-, 3-, and 6-mg luteinenriched cheeses with respect to the control $(P<0.05)$. There were considerable changes in $a^{*}$ values during ripening. The $a^{*}$ values of cheese samples with 1,3 , and $6 \mathrm{mg}$ of lutein ranged from 9.77 to 10.13 .

The results revealed that the incorporation of lutein in the cheese had an effect on $a^{*}$ value; however, it has been shown that the diet of dairy cattle can also influence the color of cheese. Seasonal variation in the color of cheese is related to changes in the concentration of $\beta$-carotene in milk (Kosikowski and Mistry, 1997). In general, consumption of green forages increases the $\beta$-carotene content of milk and cheese (Panfili et al., 1994).

The mean $b^{*}$ values are presented in Figure 3 . The $b^{*}$ value, a measure of yellowness, varied from 29.83 to 40.34 during the maturation process. The yellowness was considered significant due to the prominent pigmentation contributed by the lutein. Cheeses containing $6 \mathrm{mg}$ of lutein were much more yellow (i.e., higher $\mathrm{b}^{*}$ value) than the control, 1-, and 3-mg luteincontaining cheeses. Furthermore, the cheeses with 3 $\mathrm{mg}$ of lutein showed the lowest $\mathrm{b}^{*}$ value after $12 \mathrm{wk}$ of ripening. The $b^{*}$ values at 12 and 24 wk were significantly lower than in the first week of storage. The control $b^{*}$ value was significantly different from those of 1- and 3-mg lutein-enriched cheeses.

\section{$\mathrm{pH}$ Measurements}

The $\mathrm{pH}$ of cheese has a major influence on the cheese structure and texture (Lawrence et al., 1987; Pastorino et al., 2003). Lawrence and Gilles (1982) suggested that the texture of Cheddar cheese might be more dependent on $\mathrm{pH}$ than on any other factor. During the maturation process, $\mathrm{pH}$ changes are usually minor, but they can be significant if the cheese contains considerable amounts of residual lactose that is fermented to lactic acid (Lucey et al., 2003). Lutein did not have a significant effect $(P<0.05)$ on $\mathrm{pH}$ of the cheese during the aging process (Figure 4$)$. The $\mathrm{pH}$ increased $(P<0.05)$ with age for all cheese samples (Figure 4 ). The average $\mathrm{pH}$ value of the cheese samples (control and lutein- 


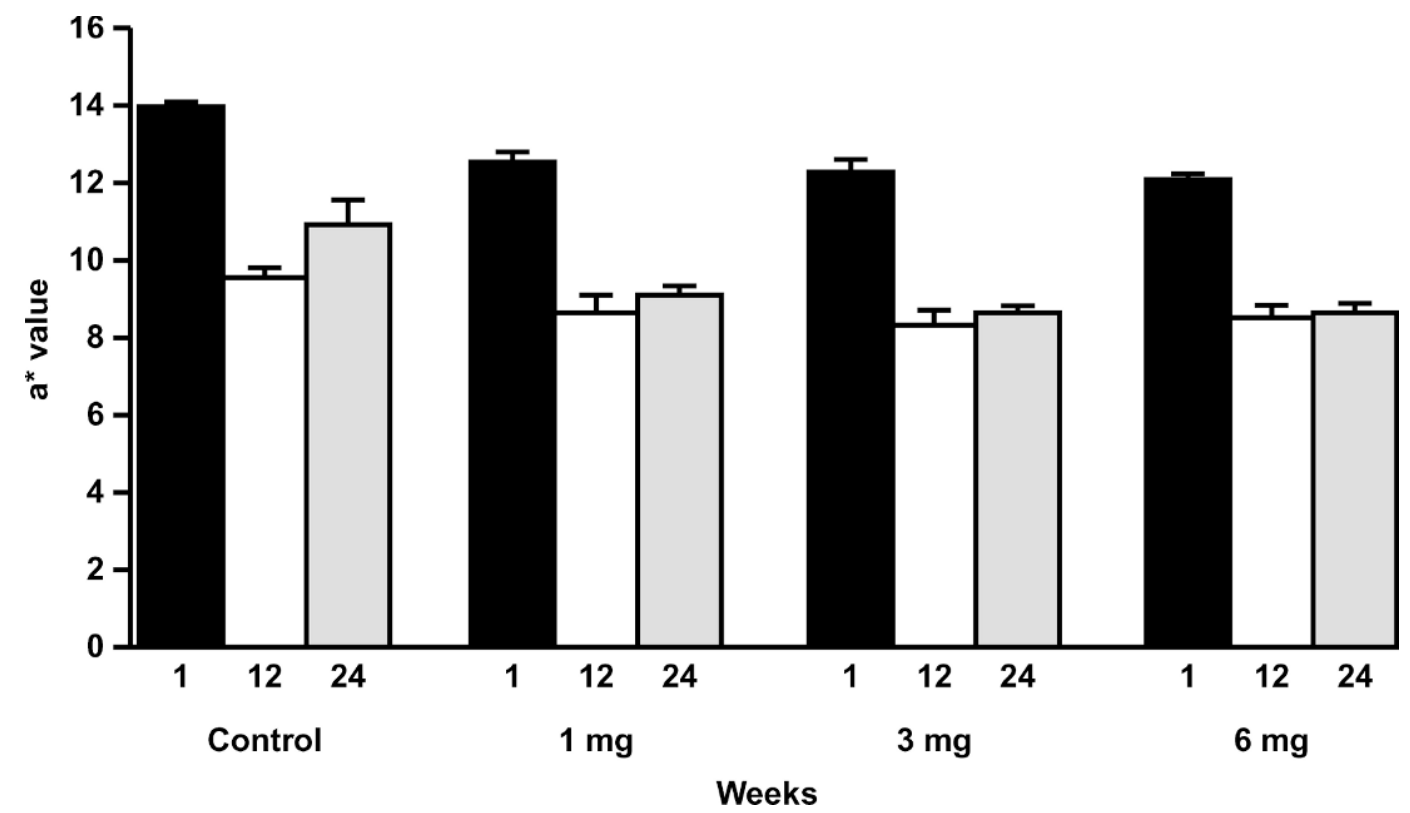

Figure 2. Redness $\left(\mathrm{a}^{*}\right)$ values (mean $\pm \mathrm{SE}$ ) of Cheddar cheese containing $0,1,3$, and 6 mg of lutein per 28-g serving for 1 , 12, and 24 wk of storage at $4.5^{\circ} \mathrm{C}$.

enriched) was 4.9 at wk 1 and increased to an average of 5.1 at wk 24 . The control cheese had the lowest $\mathrm{pH}$ throughout the 24-wk aging period. Additionally, there were no significant differences among the control or lutein-enriched cheese samples.

\section{Microbiological Analyses}

Bacterial counts. The APC (in log $\mathrm{cfu} / \mathrm{g}$ ) are reported in Figure 5. As the cheeses aged, the samples showed lowered bacterial counts. The APC for the con-

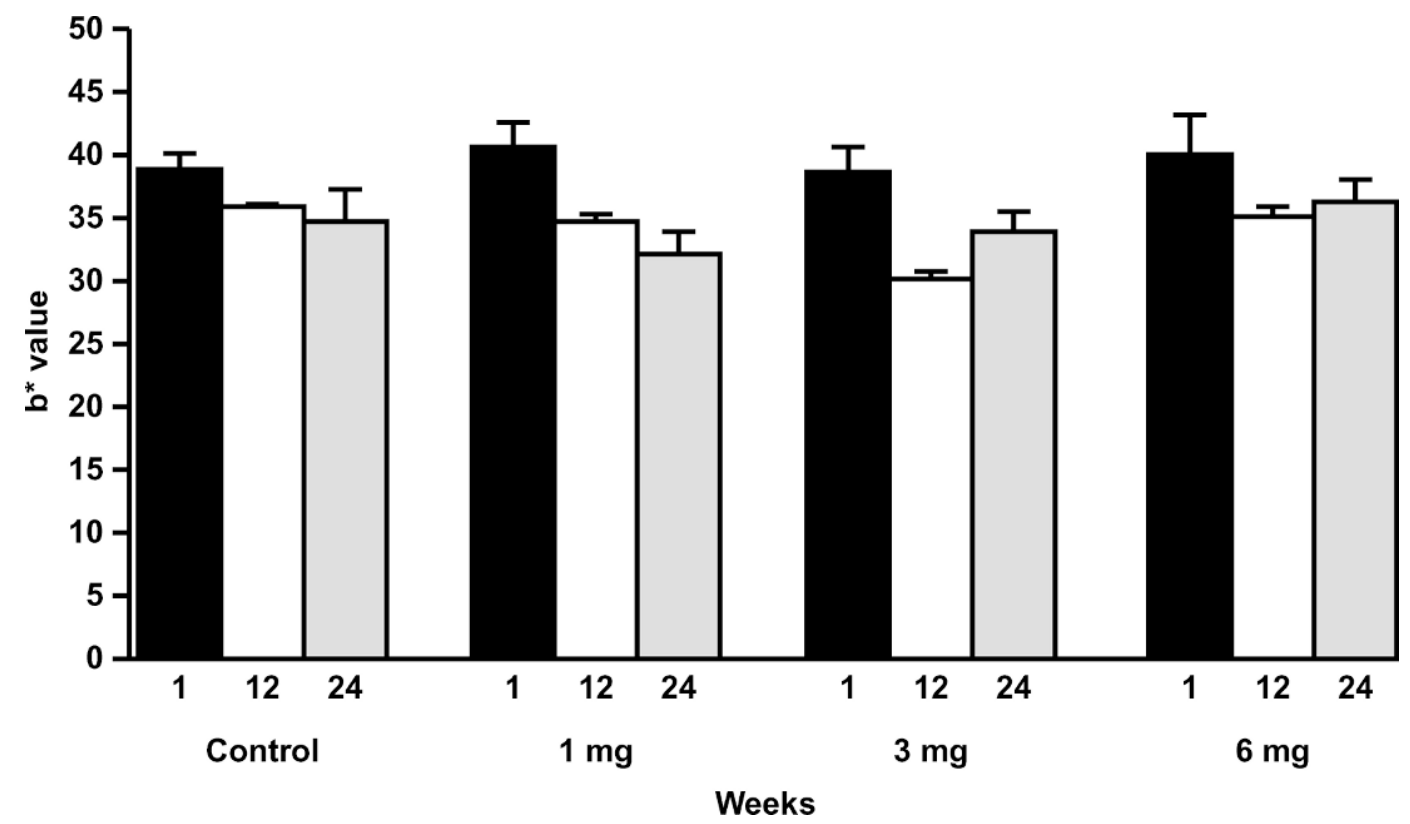

Figure 3. Yellowness $\left(b^{*}\right)$ values (mean $\pm \mathrm{SE}$ ) of Cheddar cheese containing $0,1,3$, and $6 \mathrm{mg}$ of lutein per 28-g serving for 1 , 12, and 24 wk of storage at $4.5^{\circ} \mathrm{C}$. 


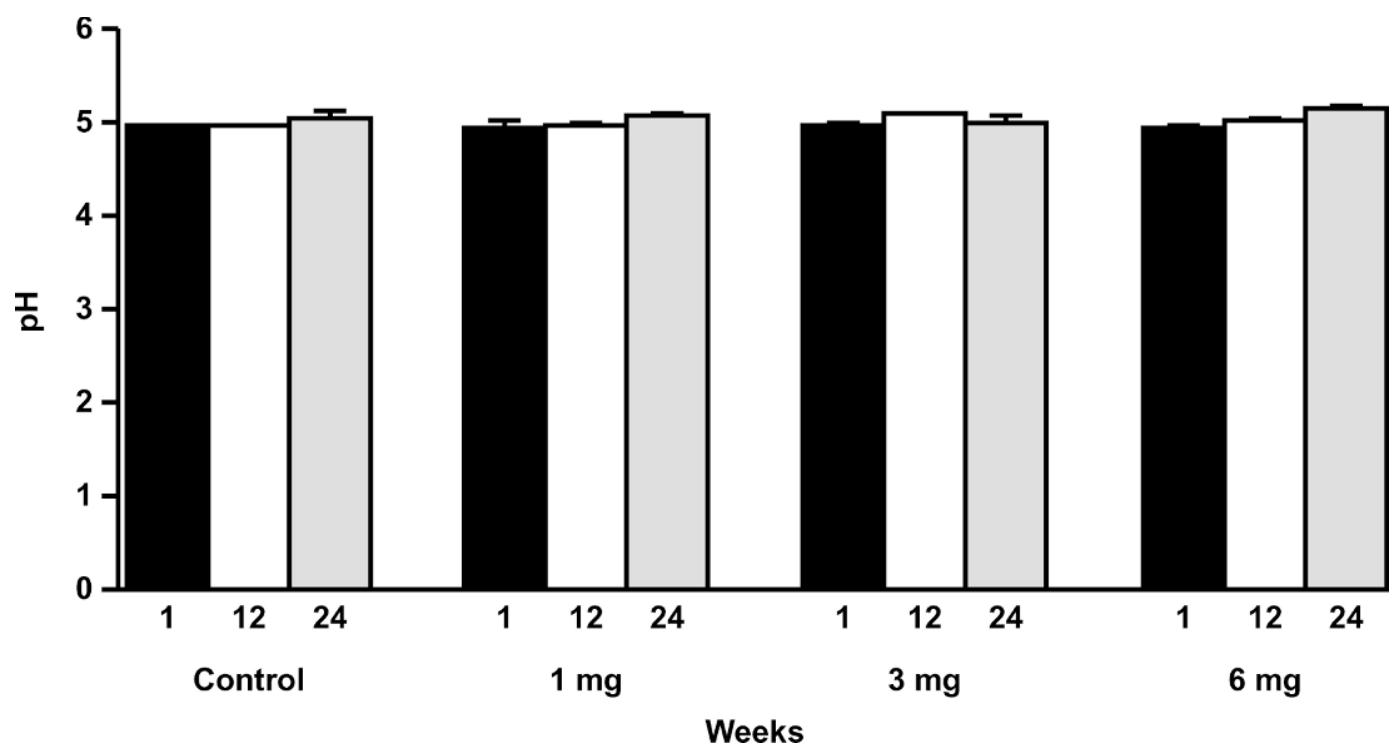

Figure 4. $\mathrm{pH}$ values (mean $\pm \mathrm{SE}$ ) of Cheddar cheese containing $0,1,3$, and $6 \mathrm{mg}$ of lutein per 28-g serving stored for 1,12 , and 24 wk at $4.5^{\circ} \mathrm{C}$.

trol cheese was significantly $(P<0.05)$ higher than for the lutein-enriched cheeses.

Among the lutein-enriched cheeses at wk 24, the 3mg lutein-enriched cheese exhibited the highest count
$(5.41 \pm 1.89 \log \mathrm{cfu} / \mathrm{g})$, whereas the 6 -mg lutein-enriched cheese showed the lowest count $(5.07 \pm 1.0 \mathrm{log} \mathrm{cfu} / \mathrm{g})$. Cheese samples contained no detectable levels of coliforms $(<10 \mathrm{cfu} / \mathrm{g})$. Typical cheese fermentation is initi-

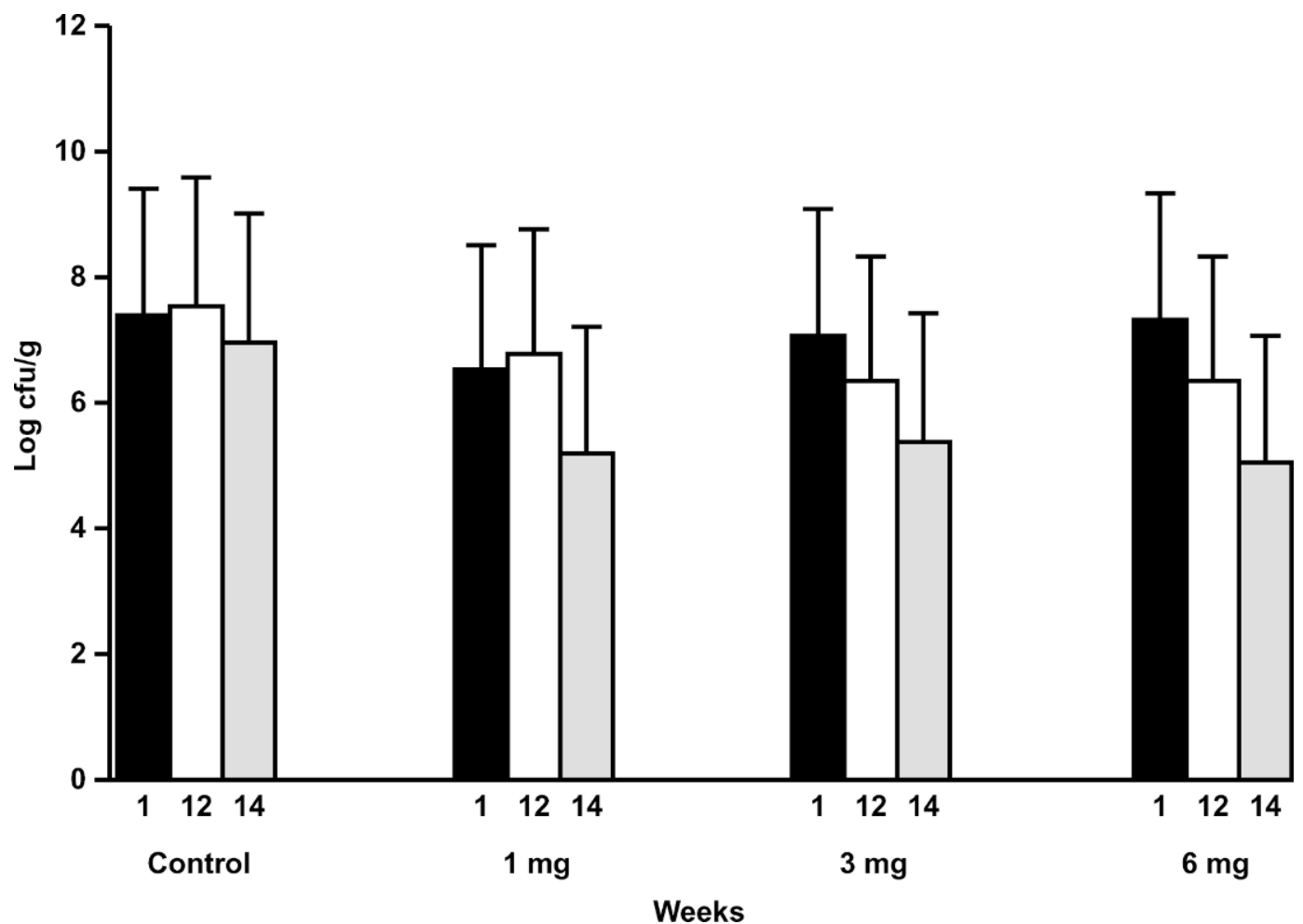

Figure 5. Aerobic plate counts of Cheddar cheese containing $0,1,3$, and $6 \mathrm{mg}$ of lutein per 28 -g serving stored at $4.5^{\circ} \mathrm{C}$. 
Table 1. Yeast/mold counts in log cfu/g (mean $\pm \mathrm{SE}$ ) of control and lutein-enriched (1, 3, and 6 mg per 28g serving size) Cheddar cheese after 1,12 , and 24 wk of storage at $4.5^{\circ} \mathrm{C}$.

\begin{tabular}{llll}
\hline & \multicolumn{2}{c}{ Time } \\
\cline { 2 - 4 } Treatment & Wk 1 & Wk 12 & Wk 24 \\
\hline Control $(0 \mathrm{mg}$ of lutein) & 0 & $0.66 \pm 0.33^{\mathrm{a}}$ & 0 \\
$1 \mathrm{mg}$ of lutein & 0 & $2.7 \pm 0.12^{\mathrm{b}}$ & $2.5 \pm 3.3^{\mathrm{b}}$ \\
$3 \mathrm{mg}$ of lutein & 0 & $4.74 \pm 0.18^{\mathrm{a}}$ & 0 \\
$6 \mathrm{mg}$ of lutein & 0 & 0 & $2.4 \pm 0.16^{\mathrm{c}}$ \\
\hline
\end{tabular}

${ }^{\mathrm{a}, \mathrm{b}, \mathrm{c}}$ Means in columns without common superscripts differ significantly $(P<0.05)$.

ated by growth of lactic acid bacteria responsible for production of lactic acid from lactose (DiLiello, 1982). Microbes mainly provide the enzymes that break down or metabolize carbohydrates, proteins, and lipids, thus improving texture and flavor during ripening. The breakdown of these products gives the characteristic cheese flavor (Haque et al., 1997). Many factors such as time, temperature, salt, $\mathrm{pH}$, and nutrient requirements affect microbial populations.

Yeast/mold counts. The $\mathrm{Y} / \mathrm{M}$ counts are reported in Table 1. Yeasts/molds were present in cheeses at wk 12 and wk 24. The control cheese had the lowest Y/M count, and the cheese with $3 \mathrm{mg}$ of lutein exhibited the highest Y/M load. The Y/M isolated from the cheese were found on random surface areas of the samples. According to Hocking and Faedo (1992), yeast and mold species have been isolated in the cheese factory environment, on cheese making equipment, in air, and in curd and whey, providing a wide range of potential sources of contamination.

\section{Sensory Evaluation}

A cheese of satisfactory flavor contains many different flavor compounds among which a good balance exists. Large changes in flavor develop during maturation. Protein has no flavor, but many degradation products contribute to the profile of the cheese. For example, free amino acid and short chain peptides contribute to the basic flavor of cheese. These compounds have specific tastes: sweet and broth-like (Walstra et al., 1999). A 5-member trained panel evaluated the cheeses after $24 \mathrm{wk}$ and found that the cheeses exhibited a distinct bitter flavor. The bitter flavor may be a result of protein degradation into short chain hydrophobic peptide formation. Bitter taste is considered a normal component of cheese taste (Soeryarpranata et al., 2002). Furthermore, it has been suggested that proteolysis of milk proteins (the major activity attributed to plasmin and other proteases) can result in off-flavor and bitterness in milk, as well as decreased cheese yield. Plasmin is the active enzyme form that is produced from the inactive zymogen called plasminogen. Conversion of plasmino- gen to plasmin occurs by specific action of plasminogen activators, which are also proteases. The result of plasmin activation is breakdown of casein ( $\beta$-casein is more susceptible than $\alpha_{\mathrm{s}}$-casein, and $\kappa$-casein is somewhat resistant to breakdown by the plasmin) (Broadbent et al., 1998). Mean sensory scores are reported in Table 2 . The cheese with $1 \mathrm{mg}$ of lutein had significantly lower sensory flavor scores compared with the control and other treatments. The 3- and 6-mg lutein-enriched cheeses were given a score of 7 , suggesting modest flavor acceptance. Differences were not observed in body/ texture or in color/appearance. However, panelists were able to detect trace amounts of red pigment in the lutein-enriched cheese samples. In contrast, as previously mentioned, $\mathrm{a}^{*}$ values (redness) showed significant differences among control and lutein-enriched cheeses. Sensory and instrumental tests are often carried out simultaneously to obtain correlations between the methods (Szczesniak, 1987). However, there have been difficulties in establishing a relationship between the 2 methods.

\section{HPLC}

To evaluate the stability of lutein, HPLC analysis following storage was carried out using a $\mathrm{YMC} \mathrm{C}_{30}$ column. The $\mathrm{C}_{30}$ carotenoid column demonstrates better selectivity against separation of carotenoid compounds compared with the $\mathrm{C}_{18}$ column (Dachtler et al., 1998). High performance liquid chromatography separation of lutein was carried out using isocratic separation with a mobile phase consisting of methyl tertiary-butyl ether:methanol (5:95) at $22^{\circ} \mathrm{C}$. Separation was carried out for $30 \mathrm{~min}$ and lutein eluted after 17 min (Figure 6). A standard curve with a correlation of 0.9971 was prepared for quantification of lutein in the samples at wk 24. There was no degradation of lutein during storage of the enriched cheeses over a 24 -wk period at $4.5^{\circ} \mathrm{C}$ (Figure 7). Corn generally contains more than one type of carotenoid. Lutein, zeaxanthin, $\beta$-cryptoxanthin, and $\alpha$ - and $\beta$-carotene are carotenoids commonly reported in corn (Kurilich and Juvik, 1999; Panfili et al., 2004). Lutein and zeaxanthin are generally the major carot- 


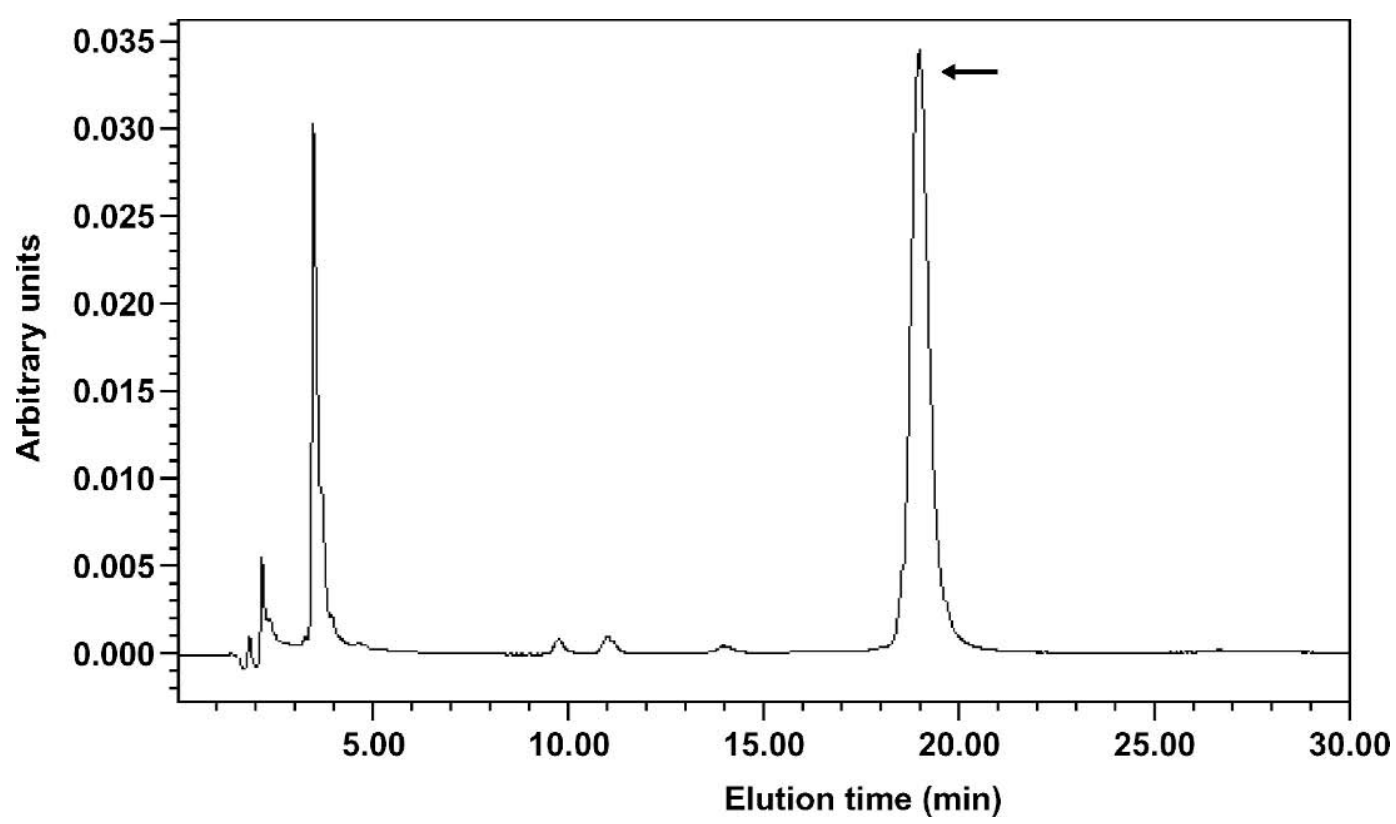

Figure 6. High performance liquid chromatography of lutein standard (50 ppm). Elution of lutein (arrow) was at a retention time of 17 min.

enoids reported in corn, with the concentration of zeaxanthin varying up to $50 \%$ (Kurilich and Juvik, 1999). However, the lutein standard used in this study was separated into 1 major lutein peak that eluted at 17 min. The peak that eluted in less than 5 min (Figures 6 and 7) was associated with the corn oil used in the process of emulsification. This peak, which absorbs at $450 \mathrm{~nm}$, shares spectral properties with carotenoids but was not a part of the lutein added to the cheese. We have demonstrated that the peak that eluted at less than 5 min was associated with the corn oil used in the process of lutein dissolution (Losso et al., accepted). The temperature during storage varied from 37 to $40^{\circ} \mathrm{C}$, thus simulating a situation that may be encountered in the commercial handling and distribution of this product. Figures 7A, B, and C show chromatograms of the lutein extracted from cheese following $1 \mathrm{wk}, 12$ wk, and $24 \mathrm{wk}$ storag. Lutein was stable during $24 \mathrm{wk}$ of ripening.

The presence of large amounts of fat, protein, and protein hydrolyzates in cheese causes complications in lutein extractions. However, saponification of the cheese samples at $22^{\circ} \mathrm{C}$ for $24 \mathrm{~h}$ helped to break the fat and isolate lutein from the cheese matrix (Renken and Warthesen, 1993).

\section{CONCLUSIONS}

The physical and chemical properties of the cheeses were monitored to evaluate the contribution of lutein to Cheddar cheese during maturation. The $\mathrm{L}^{*}$ value increased significantly from wk 1 to wk 24 during storage in the control and lutein-enriched cheeses. It can be inferred that fortification of Cheddar cheese with lutein is capable of influencing the appearance ( $a^{*}$ and $b^{*}$ values). The results revealed that the red component $\left(a^{*}\right.$ value) was significant in the lutein-enriched cheeses with respect to the control $(P<0.05)$. The b* values for 12 - and 24-wk cheeses were significantly different from those at the initial week of storage. Lutein did not have a significant effect $(P<0.05)$ on $\mathrm{pH}$ of the cheese during the aging process. As the cheeses aged, the samples

Table 2. Sensory scores (mean $\pm \mathrm{SE}$ ) of control and lutein-enriched (1, 3, and $6 \mathrm{mg}$ per 28-g serving size) Cheddar cheese after $24 \mathrm{wk}$ of storage and ripening at $4.5^{\circ} \mathrm{C}$.

\begin{tabular}{lcll}
\hline Treatment & Flavor & Body/texture & Color/appearance \\
\hline Control (0 mg of lutein) & $6.2 \pm 0.13^{\mathrm{b}}$ & $4.01 \pm 0.16^{\mathrm{a}}$ & $4.51 \pm 0.24^{\mathrm{a}}$ \\
$1 \mathrm{mg}$ of lutein & $4.67 \pm 0.58^{\mathrm{a}}$ & $3.87 \pm 0.19^{\mathrm{a}}$ & $3.57 \pm 0.29^{\mathrm{a}}$ \\
$3 \mathrm{mg}$ of lutein & $7.07 \pm 0.17^{\mathrm{b}}$ & $4.41 \pm 0.30^{\mathrm{a}}$ & $3.83 \pm 0.44^{\mathrm{a}}$ \\
$6 \mathrm{mg}$ of lutein & $7.07 \pm 0.17^{\mathrm{b}}$ & $4.25 \pm 0.25^{\mathrm{a}}$ & $3.83 \pm 0.44^{\mathrm{a}}$ \\
\hline
\end{tabular}

${ }^{\mathrm{a}, \mathrm{b}}$ Means within columns with different superscripts differ significantly $(P<0.05)$. 

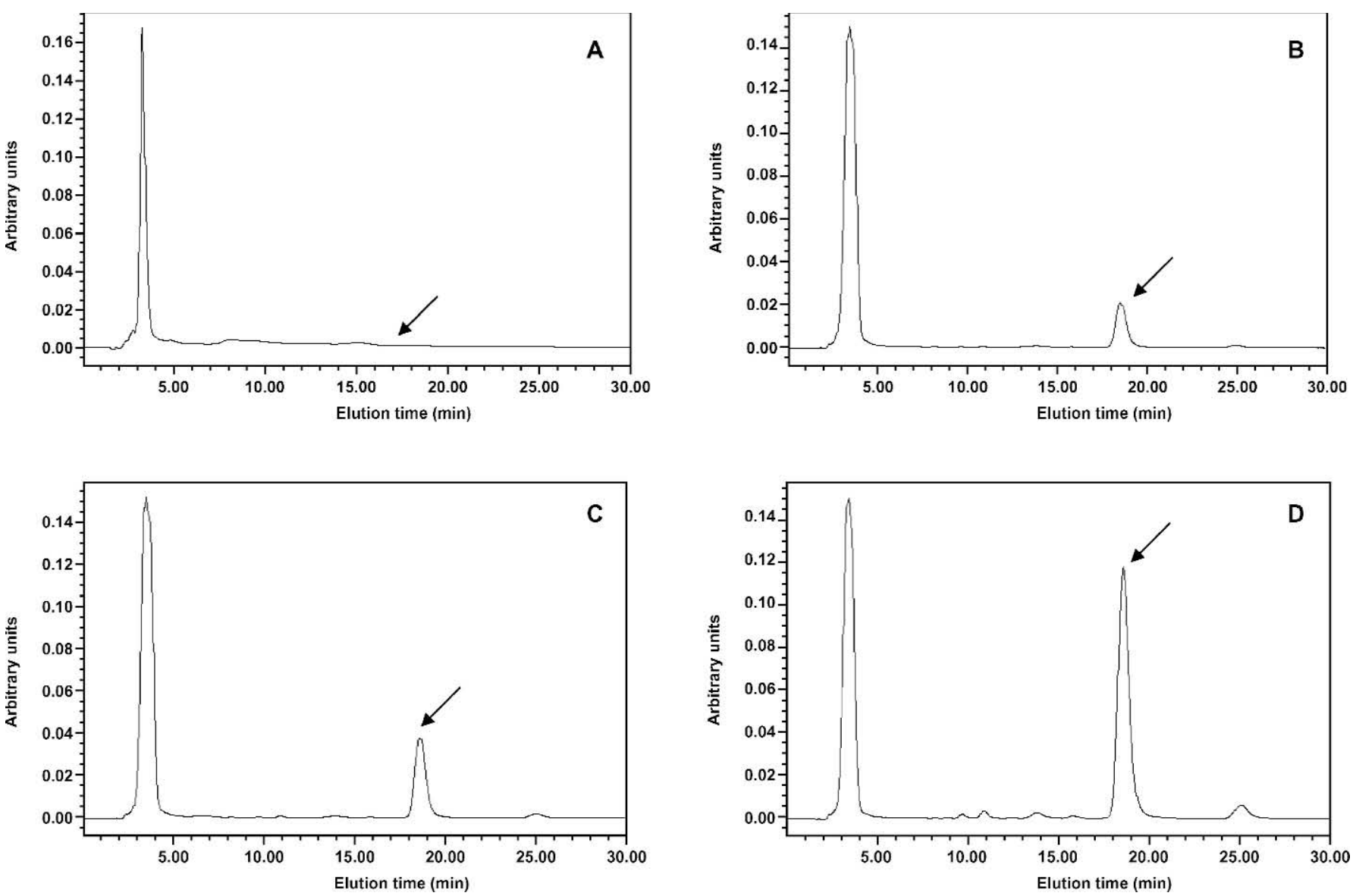

Figure 7. High pressure liquid chromatograms of lutein in Cheddar cheese after storage for $24 \mathrm{wk}$. A. Control Cheddar cheese (no lutein), B. Cheddar cheese containing $1 \mathrm{mg}$ of lutein per 28-g serving. C. Cheddar cheese containing $3 \mathrm{mg}$ of lutein per 28-g serving. D. Cheddar cheese containing $6 \mathrm{mg}$ of lutein per 28-g serving. Arrows indicate the lutein peak at 17 min (absent in control cheese sample). Separation was carried out using isocratic elution with methyl tertiary-butyl ether:methanol (5:95).

showed lowered bacterial counts. The APC for the control cheese was significantly $(P<0.05)$ higher than for the lutein-enriched cheeses. The control had the lowest Y/M count and the cheese enriched with $3 \mathrm{mg}$ of lutein exhibited the highest Y/M load. The lutein-enriched cheeses exhibited a distinct bitter flavor and had modest flavor acceptance. Differences were not observed in the sensory body/texture or in sensory color/appearance evaluations. There was no degradation of lutein during storage of the fortified cheeses over a 24 -wk period at $4.5^{\circ} \mathrm{C}$. Interestingly, Cheddar cheeses successfully fortified with lutein were manufactured. Stability of lutein during storage will help value-added cheeses play a promising role as a means for supplying this micronutrient throughout the shelf life of cheese.

\section{ACKNOWLEDGMENTS}

The financial contribution of the Louisiana Soybean and Grain Promotion and Research Board is gratefully acknowledged. We wish to thank the Department of Dairy Science Creamery for providing the milk to manufacture the Cheddar cheese. We gratefully acknowledge the cooperation and help received from Evi Menealou and Paula B. McGrew throughout this project.

\section{REFERENCES}

Age-Related Eye Disease Study Research Group (AREDS). 2001. Risk factors associated with age-related nuclear and cortical cataract: A case-control study in the Age-Related Eye Disease Study, AREDS Report No. 5. Ophthalmology 108:1400-1408.

Banavara, D. S., D. Anupama, and S. A. Rankin. 2003. Studies on physicochemical and functional properties of commercial sweet whey powders. J. Dairy Sci. 86:3866-3875.

Basu, H. N., A. J. Del Vecchio, F. Flider, and F. T. Orthoefer. 2001. Nutritional and potential disease prevention properties of carotenoids. J. Am. Oil Chem. Soc. 78:665-675.

Bernstein, P. S. 2002. New insights into the role of the macular carotenoids in age-related macular degeneration. Resonance Raman Studies. Pure Appl. Chem. 74:1419-1425.

Bonora, A., S. Pancaldi, R. Gualandri, and M. P. Fasulo. 2000. Carotenoid and ultrastructure variations in plastids of Arum italicum 
Miller fruit during maturation and ripening. J. Exp. Bot. 346:873-884.

Bowen, P. E., S. M. Herbst-Espinosa, E. A. Hussain, and M. StacewiczSapuntzakis. 2002. Esterification does not impair lutein bioavailability in humans. J. Nutr. 132:3668-3673.

Broadbent, J. R., M. Strickland, B. C. Weimer, M. E. Johnson, and J. L. Steele. 1998. Peptide accumulation and bitterness in Cheddar cheese made using single-strain Lactococcus lactis starters with distinct proteinase specificities. J. Dairy Sci. 81:327-337.

Cook, A. J., and J. E. Friday. 2003. Food mixture or ingredient sources for dietary calcium: Shifts in food group contributions using four grouping protocols. J. Am. Diet. Assoc. 103:1513-1519.

Dachtler, M., K. Kohler, and K. Albert. 1998. Reversed-phase high performance liquid chromatographic identification of lutein and zeaxanthin stereoisomers in bovine retina using a C30 bonded phase. J. Chromatogr. B Biomed. Sci. Appl. 720:211-216.

DiLiello, L. R. 1982. Methods in food and dairy microbiology. AVI Publishing Co., Inc., Westport, CT.

Eye Disease Case-Control Study Group (EDCC). 1993. Antioxidant status and neovascular age-related macular degeneration. Arch. Ophthalmol. 111:104-109.

Haque, Z. U., E. Kucukoner, and K. J. Aryana. 1997. Aging-induced changes in populations of lactococci, lactobacilli, and aerobic microorganisms in low-fat and full-fat Cheddar cheese. J. Food Prot. 60:1095-1098.

Hocking, A. D., and M. Faedo. 1992. Fungi causing thread mould spoilage of vacuum packaged Cheddar cheese during maturation. Int. J. Food Microbiol. 16:123-130.

Kosikowski, F. V. 1982. Cheese and fermented milk foods, 2nd ed. F. V. Kosikowski, Ithaca, NY.

Kosikowski, F. V., and V. V. Mistry. 1997. Page 379 in Cheese and Fermented Milk Foods. Vol. 1: Origins and Principles. F. V. Kosikowski, LLC, Westport, CT.

Krinsky, N. I., J. T. Landrum, and R. A. Bone. 2003. Biologic mechanisms of the protective role of lutein and zeaxanthin in the eye. Annu. Rev. Nutr. 23:171-201.

Kurilich, A. C., and J. A. Juvik. 1999. Quantificated of carotenoid and tocopherol antioxidants in Zea mays. J. Agric. Food Chem. 47:1948-1955.

La Cour, M., J. F. Kiilgaard, and M. H. Nissen. 2002. Age-related macular degeneration: Epidemiology and optimal treatment. Drugs Aging 19:101-133.

Lawrence, R. C., and J. Gilles. 1982. Factors that determine the $\mathrm{pH}$ of young Cheddar cheese. N.Z. J. Dairy Sci. Technol. 17:1-14.

Lawrence, R. C., L. K. Creamer, and J. Gilles. 1987. Texture development during cheese ripening. J. Dairy Sci. 70:1748-1760.

Losso, J. N., A. Khachatryan, M. Ogawa, J. S. Godber, and F. Shih. Random centroid optimization of phosphatidylglycerol stabilized oil-in-water emulsions at acidic pH. Food Chem. (accepted).

Lucey, J. A., M. E. Johnson, and D. S. Horne. 2003. Invited review: Perspectives on the basis of the rheology and texture properties of cheese. J. Dairy Sci. 86:2725-2743.

Mares-Perlman, J. A., A. Fisher, R. Klein, M. Palta, G. Block, A. E. Millen, and J. D. Wright. 2001. Lutein and zeaxanthin in the diet and serum and their relation to age-related macular maculopathy in the Third National Health and Nutrition Examination Survey. Am. J. Epidemiol. 153:424-432.
Miranda, M., M. Muriach, S. Johnsen, F. Bosch-Morell, J. Araiz, J. Roma, and F. J. Romero. 2004. Oxidative stress in a model for experimental diabetic retinopathy: Treatment with antioxidants. Arch. Soc. Esp. Oftalmol. 79:289-294.

Mississippi State Univ. Ext. Serv. 2004. Dairy Products Judging. Online. Available http://msucares.com/pubs/publications/p1423. htm.

Panfili, G., P. Manzi, and L. Pizzoferrato. 1994. High-performance liquid chromatographic method for the simultaneous determination of tocopherols, carotenes, and retinol and its geometric isomers in Italian cheeses. Analyst 119:1161-1165.

Pastorino, A. J., C. L. Hansen, and D. J. McMahon. 2003. Effect of $\mathrm{pH}$ on the chemical composition and structure-function relationships of Cheddar cheese. J. Dairy Sci. 86:2751-2760.

Pinho, O., E. Mendes, M. M. Alves, and I. M. P. L. V. O. Ferreira. 2004. Chemical, physical, and sensorial characteristics of "Terrincho" ewe cheese: Changes during ripening and intravarietal comparison. J. Dairy Sci. 87:249-257.

Renken, S. A., and J. J. Warthesen. 1993. Vitamin D stability in milk. J. Food Sci. 58:556552-556566.

Saldo, J., B. Sendra, and B. Guamis. 2002. Colour changes during ripening of high pressure treated hard caprine cheese. High Press. Res. 22:659-663.

SAS Institute. 2001. SAS User's Guide: Statistics. Version 8.02. SAS Inst., Inc., Cary, NC.

Seddon, J. M., U. A. Ajani, R. D. Sperduto, R. Hiller, N. Blair, T. C. Burton, M. D. Farber, E. S. Gragoudas, J. Haller, D. T. Miller, L. A. Yannuzzi, and W. Willett, for the Eye Disease Case-Control Study Group. 1994. Dietary carotenoids, vitamins A, C, and E, and advanced age-related macular degeneration. Eye Disease Case-Control Study Group. JAMA 272:1413-1420.

Soeryarpranata, E., J. R. Power, F. Fajarrini, K. M. Weller, H. H. Hill, Jr., and W. F. Siems, III. 2002. Relationship between MALDI-TOF analysis of $\alpha$-CN f193-209 concentration and sensory evaluation of bitterness intensity of aged Cheddar cheese. J. Agric. Food Chem. 50:4900-4905.

Stang, J., and C. T. Bayerl. 2003. Position of the American Dietetic Association: Child and adolescent food and nutrition programs. J. Am. Diet. Assoc. 103:887-893.

Stone, E. M., V. C. Sheffield, and G. S. Hageman. 2001. Molecular genetics of age-related macular degeneration. Hum. Mol. Genet. 10:2285-2292.

Szczesniak, A. S. 1987. Correlating sensory with instrumental texture measurements-an overview of recent developments. J. Text. Stud. 18:1-15.

U.S. Department of Agriculture. 2004. Food and Nutrition Service. Nutrition Assistance Programs. Online. Available http://www. fns.usda.gov/fns. Accessed July 30, 2004.

Walstra, P., T. J. Geurts, A. Noomen, A. Jellema, and M. A. J. S. van Boekel. 1999. Development of flavor. Pages 616-623 in Dairy Technology: Principles in Milk Properties and Processes. Marcel Dekker, Inc., New York, NY.

Women, Infants, and Children (WIC) Food Package. 2004. Online. Available www.fns.usda.gov/wic/benefitsandservices/foodpkgmilkfags.HTM

Zhao, D. Y., S. W. Wintch, I. V. Ermakov, W. Gellermann, and P. S. Bernstein. 2003. Resonance Raman measurement of macular carotenoids in retinal, choroidal, and macular dystrophies. Arch. Ophthalmol. 121:967-972. 